\title{
Insecticidal activity of two proteases against Spodoptera frugiperda larvae infected with recombinant baculoviruses
}

\author{
Aline Welzel Gramkow, Simone Perecmanis, Raul Lima Barbosa Sousa, Eliane Ferreira Noronha, Carlos Roberto Felix, \\ Tatsuya Nagata and Bergmann Morais Ribeiro*
}

\begin{abstract}
Background: Baculovirus comprise the largest group of insect viruses most studied worldwide, mainly because they efficiently kill agricutural insect pests. In this study, two recombinant baculoviruses containing the ScathL gene from Sarcophaga peregrina (vSynScathL), and the Keratinase gene from the fungus Aspergillus fumigatus (vSynKerat), were constructed. and their insecticidal properties analysed against Spodoptera frugiperda larvae.

Results: Bioassays of third-instar and neonate S. frugiperda larvae with vSynScathL and vSynKerat showed a decrease in the time needed to kill the infected insects when compared to the wild type virus. We have also shown that both recombinants were able to increase phenoloxidase activity in the hemolymph of $S$. frugiperda larvae. The expression of proteases in infected larvae resulted in destruction of internal tissues late in infection, which could be the reason for the increased viral speed of kill.

Conclusions: Baculoviruses and their recombinant forms constitute viable alternatives to chemical insecticides. Recombinant baculoviruses containing protease genes can be added to the list of engineered baculoviruses with great potential to be used in integrated pest management programs.
\end{abstract}

\section{Background}

Baculovirus comprise the largest group of insect viruses most studied worldwide, mainly because they efficiently kill agricultural insect pests. They are specific to one or a few related insect species [1], and have infectious particles protected in protein crystals which allows the formulation of biopesticides with easy application technology. Their use as boinsectides are a safe alternative to chemical insecticides $[2,3]$.

They are large double-stranded, circular DNA viruses with a genome size ranging from 80 to 200 kilobases (kb) [4]. Baculoviruses have enveloped rod-shaped virions and two distinct phenotypes in a single cycle of infection: the budded virus (BV), which is responsible for transmitting the virus from cell to cell and the occlusion-derived virus (ODV), which is occluded in a proteinaceus occlusion

\footnotetext{
* Correspondence: bergmann@unb.br

${ }^{1}$ Cell Biology Department, University of Brasília, Brasília, DF, CEP 70910-970, Brazil

Full list of author information is available at the end of the article
}

body, [5] and is responsible for horizontal transmission of the virus from insect to insect.

The type species of the Baculoviridae family is the Autographa californica multiple nucleopolyhedrovirus (AcMNPV) which is the most studied baculovirus at the molecular level, having a wide spectrum of hosts and has been widely used as an expression vector for heterologous proteins in insect cells and insects [6]. To speed up the death of their hosts, recombinant baculoviruses have been constructed, increasing their biopesticide properties. Some of the most effective recombinant baculoviruses are the ones containing insect-specific neurotoxins genes [7-9]. In susceptible hosts, these neurotoxins, expressed during virus infection, reduce damage to crops and decrease the time required to kill the insects from 25 to $50 \%$ when compared to larvae infected with the wild type virus [10-14].

Besides insect-specific toxins, other proteins have been introduced into the genome of baculoviruses. For instance, one of the first effective recombinant baculovirus constructed with the intention of improving biologi- 
cal control, contained the diuretic hormone gene from Manduca sexta that, when injected into larvae of Bombyx mori, was able to kill the insects $20 \%$ faster than wild-type virus [15]. The wild type and mutant juvenile hormone esterase (JHE) genes from Heliothis virescens were also inserted into the genome of AcMNPV [16-19]. The wild type JHE gene has shown an improvement on AcMNPV pathogenicity only towards Trichoplusia ni neonate larva [16]. However, mutated versions of the JHE gene that improved protein stability also showed increased pathogenicity towards $H$. virescens larvae [20]. Some baculoviruses produce during infection, the enzyme Ecdysteroid UDP-Glycosyl Transferase (EGT), which inactivates the hormone ecdysone of their hosts [21,22]. The deletion or inactivation of the egt gene can also results in reduced infected-insect time to death and reduced economic damage to crops $[21,23]$.

Recombinant baculoviruses have also been constructed with enhancin genes from other baculoviruses. These recombinants were based on AcMNPV and were designed to improve the ability of the virus to gain access to midgut epithelium cells [24-26]. Also chitinases of some insects pathogens have also been used to increase baculovirus pathogenicity $[27,28]$. Some entomopathogenic microbes produce chitinases to penetrate the insect host body [27,29] and baculoviruses themselves also produce chitinases to liquefy the host body after their death by viral infection $[30,31]$. Another type of toxin gene used with the purpose of increasing baculovirus pathogenicity is the Cry toxin gene from Bacillus thuringiensis (Bt). Some Cry toxin genes were inserted into AcMNPV genome and shown to produce large amounts of biological active toxins [32-37]. However, only a Cry toxin fused with the major occlusion body protein (polyhedrin) of the baculovirus AcMNPV was capable of improving the virus pathogencity towards its insect host [37].

The only protease gene used with the aim of improving insecticidal activity of baculoviruses was the cathepsin- $\mathrm{L}$ (ScathL) gene of Sarcophaga peregrina, which showed reduced survival time and damage caused by infected larvae when compared with the wild virus [38].

Spodoptera frugiperda (Lepidoptera: Noctuidae) is a polyphagous species that attacks many economically important crops in several countries. In Brazil, this insect can attack the following crops: corn, sorghum, rice, wheat, alfalfa, beans, peanuts, tomato, cotton, potatoes, cabbage, spinach, pumpkin and cabbage $[39,40]$.

Aspergillus fumigatus is found in nature as an opportunistic pathogen of the airways, affecting humans, birds and other animals. It is responsible for a variety of respiratory diseases and many invasive infections. This fungus produces many proteolytic enzymes such as elastases
[41-43], serine proteases [44] and collagenases [45], which are involved in many key events in the pathophysiology of A. fumigatus [46]. The Keratinase of the fungus A. fumigatus has been isolated, purified and characterized previously [46].

In this study, we constructed recombinant baculoviruses containing the ScathL gene from S. peregrina, and the Keratinase gene from the fungus $A$. fumigatus, under the command of two promoters in tanden and analysed their insecticidal properties against S. frugiperda larvae.

\section{Methods}

\section{Virus and cell}

Trichoplusia $n i$ insect cells (BTI-Tn5B1-4) [47] and/or $S$. frugiperda IPLB-Sf21-AE (Sf-21) [48] were kept at $27^{\circ} \mathrm{C}$ in TC-100 medium supplemented with $10 \%$ fetal bovine serum (GIBCO-BRL). These cell lines were used for the in vitro propagation of AcMNPV and the recombinant vSynVI-gal, which contains the $\beta$-galactosidase (lac-Z) gene in place of the polh gene [49], and were also used for the construction of the recombinant viruses containing the ScathL and Keratinase genes, respectively.

\section{Construction of recombinant plasmids and viruses}

The cathepsin-L (ScathL) gene from S. peregrina was amplified by PCR using specific oligonucleotides (Protease $\mathrm{F}$ 5'-CCACCAGCAACCATCACCTTAAGCTTTAACAC-3') (Protease R 5'GAATTCAATTGAAAAAGGCAG-3') and DNA from the pKYH5 plasmid (courtesy of Dr. Robert Harrison, Iowa State University, USA). The Protease F oligonucleotide anneals at positions -10 to -35 and relative to the start codon (ATG) and the Protease R oligonucleotide anneals to positions +76 to +91 relative to the last nucleotide of the stop codon (TAA) of the ScathL gene. The position of the HindIII and EcoRI restriction sites are shwon in italics, respectively. The amplified fragment was then cloned into vector pGEM ${ }^{\circ}-\mathrm{T}$ following the manufacturer's instructions (Promega). The plasmid pGEMScathL containing the gene for ScathL was digested with NcoI (Invitrogen) and NotI (Promega), the resulting fragment was separated by electrophoresis in an agarose gel $(0.8 \%)$ and the fragment of $1,100 \mathrm{bp}$, corresponding to the ScathL gene was purified using the DNA extraction Perfect Gel Cleanup kit, according to manufacturer's instructions (Eppendorf). Next, we carried out a T4 DNA polymerase reaction (Invitrogen) using the purified fragment in order to create blunt ends, following the manufacturer's instructions (Invitrogen) and ligated the fragment to the transfer vector pSynXIVVI+X3 [49], which enables insertion of the heterologous gene under the control of two promoters in tandem (pSyn and pXIV) 
[49], and previously digested with SmaI and dephosphorylated, according to the manufacturer's protocol (Promega). Escherichia. coli DH5 $\alpha$ cells were transformed with the ligation by electroporation [50] and the recombinant plasmid (pSynScathL) was obtained. The plasmid pGEMKerat containing the Keratinase gene from $A$. fumigatus [46] was amplified in DH5 $\alpha$ cells of $E$. coli and purified using the DNA extraction Concert kit, according to manufacturer's instructions (Invitrogen). The plasmid was digested with EcoRI (GE), the DNA fragment corresponding to $1,200 \mathrm{bp}$ was purified from an agarose gel (0.8\%), using the GFX DNA extraction kit, according to the manufacturer's instructions (GE). The purified fragment was ligated with the EcoRI-digested and dephosphorilated transfer vector pSynXIVVI+X3 [49], using the Rapid DNA Ligation kit following the manufacturer's instructions (Promega). The ligation product was then used to transform DH5 $\alpha$ cells in order to obtain the transfer vector pSynKerat.

The plasmid DNAs from pSynScathL and pSynKerat (1 $\mu \mathrm{g}$ each) were separately co-transfected with the DNA $(0.5 \mu \mathrm{g})$ of the Bsu36I-linearized vSynVI-gal recombinant virus in BTI-TN-5B1-4 cells $\left(10^{6}\right)$, using liposomes following the manufacturer's instructions (CellFectin', Invitrogen ).

Seven days after co-transfection, the supernatants of the co-transfected cells were collected and used for the isolation of the recombinant viruses vSynKerat and vSynScathL by serial dilution in 96-well plates [51].

\section{Bioassays}

Thirty $3^{\text {rd }}$ instar S. frugiperda larvae (for each virus) were injected with $10 \mu \mathrm{l}$ of each viral stock (approximately $1 \times$ $10^{6} \mathrm{pfu}$ ) into the hemolymph, as a negative control, thirty S. frugiperda larvae were also injected with culture medium and the experiment was repeated three times. The inoculated larvae were placed individually in plastic cups with artificial diet and observed twice daily until death. Statistical analysis was performed using the Polo Plus program (LeOra Software).

Bioassays with occluded viruses were conducted using the droplet feeding method [52] with five different concentrations of occlusion bodies per nanoliter $\left(10^{2}, 10^{1}\right.$, $1.0,0.1,0.01$ occlusion bodies $/ \mathrm{nL}$ ). Thirty neonate larvae of S. frugiperda were used for oral inoculation with the different viral doses from each of the recombinant viruses, the wild type AcMNPV and with only dye (2\% phenol red) as negative control. Mortality was scored until 10 d.p.i. and the data analyzed by probit analysis using the Polo Plus program (LeOra Software). The insects were monitored every eight hours for ten days. The inoculated larvae were placed individually in plastic cups with artificial diet and the experiment was repeated three times. The mean time to death (TD) was calculated according to Morales et al. [53].

\section{Structural and ultrastructural analysis of the internal tissues of virus-infected S. frugiperda larvae}

Ten $3^{\text {rd }}$ instar $S$. frugiperda larvae were injected with the recombinant viruses as described above and dissected at different times post infection. The insects were dissected by cutting along their backs with an entomological scissors to expose the gut and other organs and were photographed under a stereomicroscope (Stemi SV 11, Zeiss). An uninfected larvae was used as control. Furthermore, the infected insects were also prepared for scanning electron microscopy, as described in Matos et al. [54]. Briefly, the infected insects were fixed in a solution of $2 \%$ glutaraldehyde and $2 \%$ paraformaldehyde in sodium cacodylate buffer $0.1 \mathrm{M}, \mathrm{pH} 6.4$ for $2 \mathrm{~h}$ at $4{ }^{\circ} \mathrm{C}$, washed by 3 cycles of 15 min with cacodylate buffer $0.1 \mathrm{M}$ and post-fixed in osmium tetroxide and 1:1 potassium ferrocyanide for $2 \mathrm{~h}$ and then dehydrated with an ascending series of acetone and then dried (Balzer CPD30 critical point drier) and covered with gold in an sputter coater apparatus (Balzer SCD 050). The samples were then analyzed in a scanning electron microscope JEOL JSM 840 at $10 \mathrm{kV}$.

\section{Phenoloxidase activity}

Third-instar S. frugiperda larvae were separately inoculated with BV stocks $\left(10^{8} \mathrm{pfu} / \mathrm{mL}\right)$ with AcMNPV, vSynScathL, vSynKerat and mock infected as described above. At $72 \mathrm{~h}$ p.i., haemolymph was collected and placed into $100 \mu \mathrm{l}$ of anticoagulant buffer $(0.098 \mathrm{M} \mathrm{NaOH}, 0.186 \mathrm{M}$ $\mathrm{NaCl}, 0.017 \mathrm{M}$ EDTA, $0.041 \mathrm{M}$ Citric acid) and used for detection of phenoloxidase activity. Briefly, hemolymph samples were kept on ice, and hemocytes were pelleted by centrifugation at 3,000 $\times g$ for $5 \mathrm{~min}$ at $4^{\circ} \mathrm{C}$. The cell-free hemolymph, $113 \mu \mathrm{g}$, was then transferred to a tube containing $800 \mu \mathrm{L}$ of $10 \mathrm{mM} \mathrm{L}-3,4-$ dihydroxyphenylalanine (L-DOPA) and incubated for $20 \mathrm{~min}$ at $25^{\circ} \mathrm{C}$ and the mixture analyzed in a spectrophotometer at $475 \mathrm{~nm}$.

\section{Results}

\section{Construction of recombinant plasmids and viruses}

The ScathL gene from S. peregrina was amplified by PCR from pKYH5 plasmid DNA and cloned into the vector pGEM ${ }^{\circ}-\mathrm{T}$ Easy (data not shown). The DNA fragment containing the gene was removed from the cloning vector by digestion with restriction enzymes and cloned into the transfer vector pSynXIVVI+X3 forming a new plasmid, called pSynScathL (data not shown). Similarly, the Keratinase gene was removed from a cloning vector by digestion with restriction enzymes and cloned into the transfer

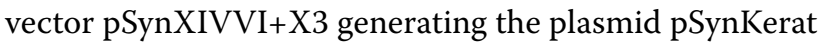


(data not shown). The recombinant viruses were constructed by separetely co-tranfecting insect cells with the pSynScathL and pSynKerat DNA and DNA from the recombinant vSynVI-gal in BTI-Tn5B1-4 cells. Within the insect cells, homologous recombination occurred between regions of the plasmid vector and viral genome. The recombinant viruses vSynScathL and vSynKerat were then isolated from the supernatant of co-transfected insect cells by end-point dilution (Figure 1).

\section{Bioassays}

Thirty $3^{\text {rd }}$ instar S. frugiperda larvae were separetely inoculated with aproximately $10^{6} \mathrm{pfu}$ per larvae of each recombinant and wild type virus via hemolymph. The recombinants vSynScathL and vSynKerat were able to induce insect death faster than the wild-type virus (Table 1). The vSynScathL showed a $\mathrm{LT}_{50}$ and a mean time to death (TD) of $47 \mathrm{~h}$ and 2.62 days, respectively, while the AcMNPV, a $\mathrm{LT}_{50}$ of $136 \mathrm{~h}$ and a TD of 5.37 days, respectively. This represents a significant $65.5 \%$ reduction in the time needed to kill the virus infected insects when compared to the wild type virus. The $\mathrm{LT}_{50}$ and $\mathrm{TD}$ for the vSynKerat were $91 \mathrm{~h}$ and 3.70 days, respectively, with represents a reduction of $32.8 \%$ compared to AcMNPV. Moreover, in the final stages of infection, viruses with the ScathL and Kerat genes induced melanization of the cuticle, which was not observed with AcMNPV infected insects (Figure 2).

Droplet feeding bioassays were also carried out with neonate $\mathrm{S}$. frugiperda larvae with different concentrations of occlusion bodies from AcMNPV, vSynScathL and
vSynKerat. The recombinant vSynScathL was also shown to induce death in neonate larvae faster compared to wild-type virus (Table 2). The vSynScathL showed a LT50 of $77 \mathrm{~h}$ while the AcMNPV, a LT50 of $104 \mathrm{~h}$ when inoculated with $102 \mathrm{PIBs} / \mathrm{nL}$. This represents a reduction of $26 \%$ in the time needed to kill the infected insects when compared to the wild type virus. The LT50 for the virus vSynKerat was $54 \mathrm{~h}$, with a reduction of $48 \%$ compared to the virus AcMNPV. We also analysed the LC50 for the two recombinants but no significant difference was observed when compared with the wild type virus (Table $3)$.

\section{Structural and ultrastructural tissue analysis of S. frugiperda larvae infectecd with different viruses}

S. frugiperda larvae uninfected and infected with AcMNPV, vSynScathL and vSynKerat were examined under a stereomicroscope (Figure 3) and a scanning electron microscope (Figure 4). The larvae infected with AcMNPV showed the presence of fat tissue (Figure 3) and tracheal system firmly attached to the gut of the caterpillar (Figure 4). On the other hand, larvae infected with vSynScathL (Figure 2) and vSynKerat (Figure 2) showed melanization of the cuticle, had little or no fat tissue and tracheal system was loosely connected to the midgut of the insect (Figure 4).

\section{Phenoloxidase activity}

Phenoloxidase activity was determined spectrophotometrically by measuring formation of dopachrome from L-DOPA at $475 \mathrm{~nm}$ in haemolymph samples from insects infected with vSynScathL, vSynKerat, AcMNPV and

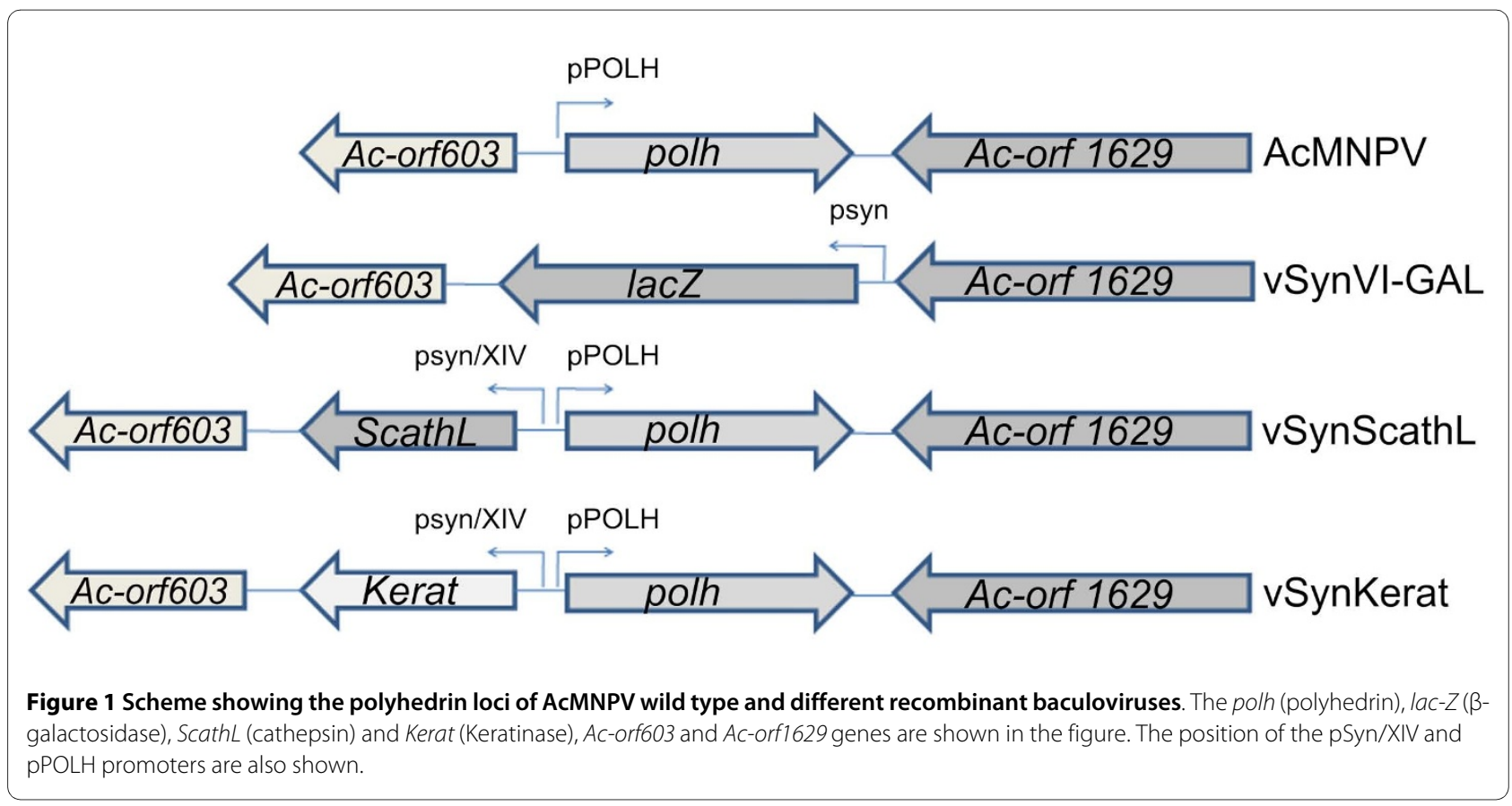


Table 1: $\mathbf{L T}_{50}$ values for the wild type and recombinant viruses in $3^{\text {rd }}$ instar S. frugiperda larvae.

\begin{tabular}{lllll}
\hline Virus & LT $_{\mathbf{5 0}}$ & $\begin{array}{l}\text { CL (95\%) } \\
\text { Lower }\end{array}$ & $\begin{array}{l}\text { CL (95\%) } \\
\text { Upper }\end{array}$ & TD/SD \\
\hline AcMNPV & 136.15 & 119.91 & 161.86 & $5.23(+/-0.28)$ \\
vSynScathL & 47.00 & 33.51 & 57.60 & $2.61(+/-0.07)$ \\
vSynKerat & 91.44 & 78.28 & 105.14 & $3.65(+/-0.36)$ \\
\hline
\end{tabular}

$\mathrm{LT}_{50}$ : Letal Time in $50 \%$ of the larvae, in hours

$\mathrm{CL}$ : conficdence limits at $95 \%$

TD: mean time to death in days

SD: standard deviation

Larvae were injected with $10^{6} \mathrm{pfu} / \mathrm{larva}$ into the hemolymph with the recombinant baculoviruses vSynScathL and vSynKerat and the wild type virus.

mock infected (figure 5). We observed an expressive increase in phenoloxidase activity in haemolymph from $S$. frugiperda larvae infected with vSynScathL (0.23) and vSynKerat (0.17) when compared with haemolymph from mock-infected (0.10) and AcMNPV-infected insects (0.05). The experiment was repeated three times.

\section{Discussion}

The introduction of heterologous genes into baculoviruses genomes has been performed for various purposes, such as to increase the virulence of these viruses towards their hosts $[3,55]$ and for expression of heterologous proteins in cultured insect cells and insects $[56,51,57,58]$.

Different genes have been introduced into the genome of baculovirus aiming the improvement of their pathogenicity towards their hosts. For instance, AcMNPV recombinants expressing wild type and mutated versions of JHE were able to improve viral pathogenicity and reduce the consumption of food by the larvae of $H$. virescens and $T$. $n i[16,59,20]$. The TxP-1 toxin gene from the mite Pyemotes tritici, was introduced into the genome of the AcMNPV and shown to have an improved insecticidal activity. The recombinant baculovirus expressing TxP-1 had a reduction of $30-40 \%$ in the time to induce insect death when compared to the wild type virus $[60,13,61]$. Similar results were found with the introduction of the scorpion toxin AaIT gene from Androctonus australis with lethal time reduced by $25-40 \%$ when compared to wild-type virus $[11,12,62,8]$. Other toxins from scorpions $[63,64]$, spiders [65], sea anemones [65] and B. thuringiensis [34,35,37] were also expressed using recombinant baculoviruses, and most of them showed an improvement on the virus speed of kill. Strong promoters as those in the transfer vector pSynXIVVI+X3 $[49,51]$ are widely


Figure 2 Structural analysis of the cuticle of larvae of S. frugiperda observed in a stereomicroscope. Uninfected larvae (A) and infected with type virus AcMNPV (120 h.p.i.) (B), recombinant vSynScathL (96 h.p.i.) (C), vSynKerat (96 h.p.i.) (D). Note melanization of cuticle in the larvae infected with vSynScathL and vSynKerat. Bar $=0.38 \mathrm{~cm}$. 
Table 2: $\mathbf{L T}_{50}$ values for the wild type and recombinants vSynScathL and vSynKerat in neonate S. frugiperda larvae.

\begin{tabular}{lllll}
\hline Virus & LT $_{\mathbf{5 0}}$ & $\begin{array}{l}\text { CL (95\%) } \\
\text { lower }\end{array}$ & $\begin{array}{l}\text { CL (95\%) } \\
\text { Upper }\end{array}$ & TD/SD \\
\hline AcMNPV & 104 & 94.07 & 112.05 & $4.16 /(+/-0.6)$ \\
vSynScathL & 77 & 49.26 & 93.91 & $3.46 /(+/-0.4)$ \\
vSynKerat & 54 & 37.71 & 71.29 & $3.87(+/-0.58)$ \\
\hline
\end{tabular}

$\mathrm{LT}_{50}$ : Letal Time in $50 \%$ of the larvae, in hours

CL: conficdence limits at 95\% TD: mean time to death in days

SD: standard deviation

Larvae were inoculated with $10^{2}$ occlusion bodies/nL with the recombinant baculoviruses vSynScathL and vSynKerat and the wild type virus

used for high levels of heterologous protein expression in insect cells. This vector has two promoters in tanden (pSyn and PXIV) that are active from the viral late through the very late phases of transcription [49] and are responsible for the high levels of heterologous protein expression during infection. This vector also have the polh gene that facilitates detection and isolation of recombinant viruses when co-transfected with occlusion negative (occ-) viral DNA.

Recombinant baculoviruses expressing proteases that potentially degrade the basement membrane of tissues of insects have also been developed. A recombinant AcMNPV was constructed with the introduction of the ScathL gene from S. peregrina, under the command of the $p 6.9$ promoter, and significantly reduced $(49 \%)$ the survival time of infected neonate $H$. virescens larvae and the their consumption of food when compared to the wild type virus [38].

In this work, we inserted the genes of ScathL of S. peregrina and Keratinase of A. fumigatus in the genome of the baculovirus AcMNPV by using the vector pSynXIVVI+X3 and analysed the effect on viral pathogenicity. The recombinant vSynScathL constructed in this work confirmed the data previously shown by Harrison et al.
[38] showing that the expression of the ScathL gene increase viral speed of kill when compared to the wild type AcMNPV. The recombinant vSynScathL showed a $\mathrm{LT}_{50}$ of $47 \mathrm{~h}$ while the AcMNPV, a $\mathrm{LT}_{50}$ of $136 \mathrm{~h}$, which represents a significant reduction of $65.5 \%$ in the survival time of $S$. frugiperda when $10^{6}$ pfu of BVs were innoculated into the hemolymph of third-instar larvae. Furhthermore, the vSynScathL showed a $26 \%$ reduction in survival time when neonate S. frugiperda larvae were orally inoculated with $10^{2}$ occlusion bodies/nL. Harrison et al. [38] showed a $49 \%$ reduction in survival time of neonate $H$. virescens when infected with a AcMNPV recombinant containing the ScathL gene under the control of the $p 6.9$ promoter (AcMLF9.ScathL) when compared to the wild type AcMNPV. Furthermore, Li et al. [66] have shown that purified ScathL was able to kill insects in the absence of baculovirus infection by injecting the protease into the hemocoel. The difference in larval survival time from the work by Harrison et al. [38] and this work, might be due to the diferent promoters used for the expression of the ScathL gene and the different viral susceptibilty of the insects tested, since $S$. frugiperda has been shown to be $1000 \times$ less susceptible to AcMNPV by

Table 3: $\mathrm{LC}_{50}$ values for the wild type and recombinants vSynScathL and vSynKerat in neonate $S$. frugiperda larvae.

\begin{tabular}{lllll}
\hline Virus & $\begin{array}{l}\text { LC }_{\mathbf{5 0}} \\
\text { (occlusion bodies/nL) }\end{array}$ & $\begin{array}{l}\text { CL (95\%) } \\
\text { Lower }\end{array}$ & $\begin{array}{l}\text { CL (95\%) } \\
\text { Upper }\end{array}$ & $X^{\mathbf{2}(\mathbf{d f})}$ \\
\hline AcMNPV & 32.32 & 19.10 & 47.84 & $1.49(3)$ \\
vSynScathL & 8.15 & 1.73 & 26.72 & $3.99(3)$ \\
vSynKerat & 30.41 & 17.58 & 51.17 & $1.28(3)$ \\
\hline
\end{tabular}

$\mathrm{LC}^{50}$ : Letal Concentration in $50 \%$ of the larvae, in occlusion bodies $/ \mathrm{nL}$

$\mathrm{CL}$ : conficdence limits at $95 \%$,

$x^{2}$ : qui-square

df: degrees of freedom.

Larvae were inoculated with different doses of occlusion bodies with the recombinant baculoviruses vSynScathL and vSynKerat and the wild type virus. 


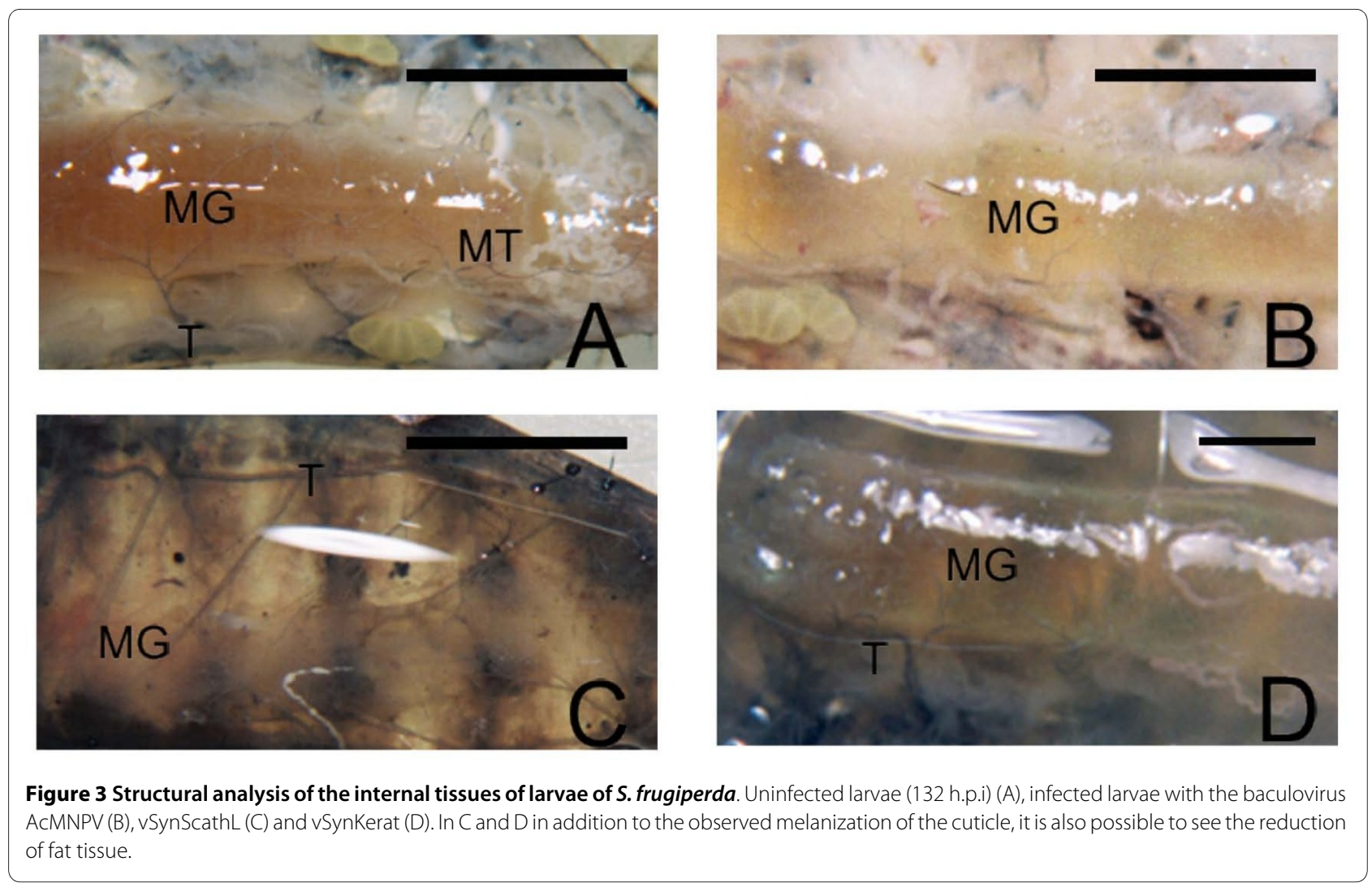

oral inoculaton when compared to the more susceptible T. ni larvae [67].

We also introduced the Keratinase (a serine protease) gene from the fungus A. fumigatus into the AcMNPV genome using the same vector and also showed an increase in viral speed of kill towards S. frugiperda. The virus vSynKerat showed a $32.8 \%$ reduction in the $\mathrm{LT}_{50}$ when compared to wild type virus when $10^{6} \mathrm{pfu}$ of BVs were innoculated into the hemolymph of third instar larvae and $48 \%$ reduction when $10^{2}$ occlusion bodies $/ \mathrm{nL}$ were administered to neonate larvae. Fungal serine proteases are known for their elastinolytic properties that enhance fungus invasiveness $[68,69]$. The production of A. fumigatus serine proteases capable of degrading elastin and mucin, among various other substrates has been previously observed [70]. Since the recombinant virus constructed in this work (vSynKerat) possesses a serine protease from A. fumigatus we would expect that the expression of this protein inside infected insect larvae would increase virus pathogenicity similarly to the ScathL by degrading extracellular matrix proteins and/or interfering with the phenoloxidase activity of the insect host. The $\mathrm{LC}_{50}$ for the two recombinants did not show significant differences when compared with the wild type virus (Table 2).
The melanization of the cuticle observed in insects infected with the recombinants vSynScathL and vSynKerat may have been caused by the activation of the insect phenoloxidase enzyme, found in the form of a proenzyme in the hemolymph. In invertebrates, the presence of antigens and the appearance of tissue damage results in the deposition of melanin around the damaged tissue or antigen as well as sclerotization of the cuticle [71]. Melanization of the cuticle and tissue damage, including rupture of the intestine and fragmentation of the fat tissue has been previously shown in larvae of $H$. virescens infected with a recombinant AcMNPV containing the ScathL gene $[38,72,73]$, suggesting that ScathL was able to cause tissue fragmentation prior to insect death and activate the cascade triggered by serine proteases leading to conversion of pro-phenoloxidase in its active form phenoloxidase. However, Li et al. [66] have shown that the cystein protease activity of purified ScathL was not able to activate pro-phenoloxidase to phenoloxidase in vitro and the phenoloxidase activity in the hemolymph of $H$. virescens larvae was not altered by a recombinant AcMNPV containing the ScathL gene under the baculovirus basic $p 6.9$ promoter (AcMLF9.ScathL).

We have shown that both recombinants (vSynScathL and vSynKerat) containing the ScathL and Keratinase genes under the command of strong promoters were able 

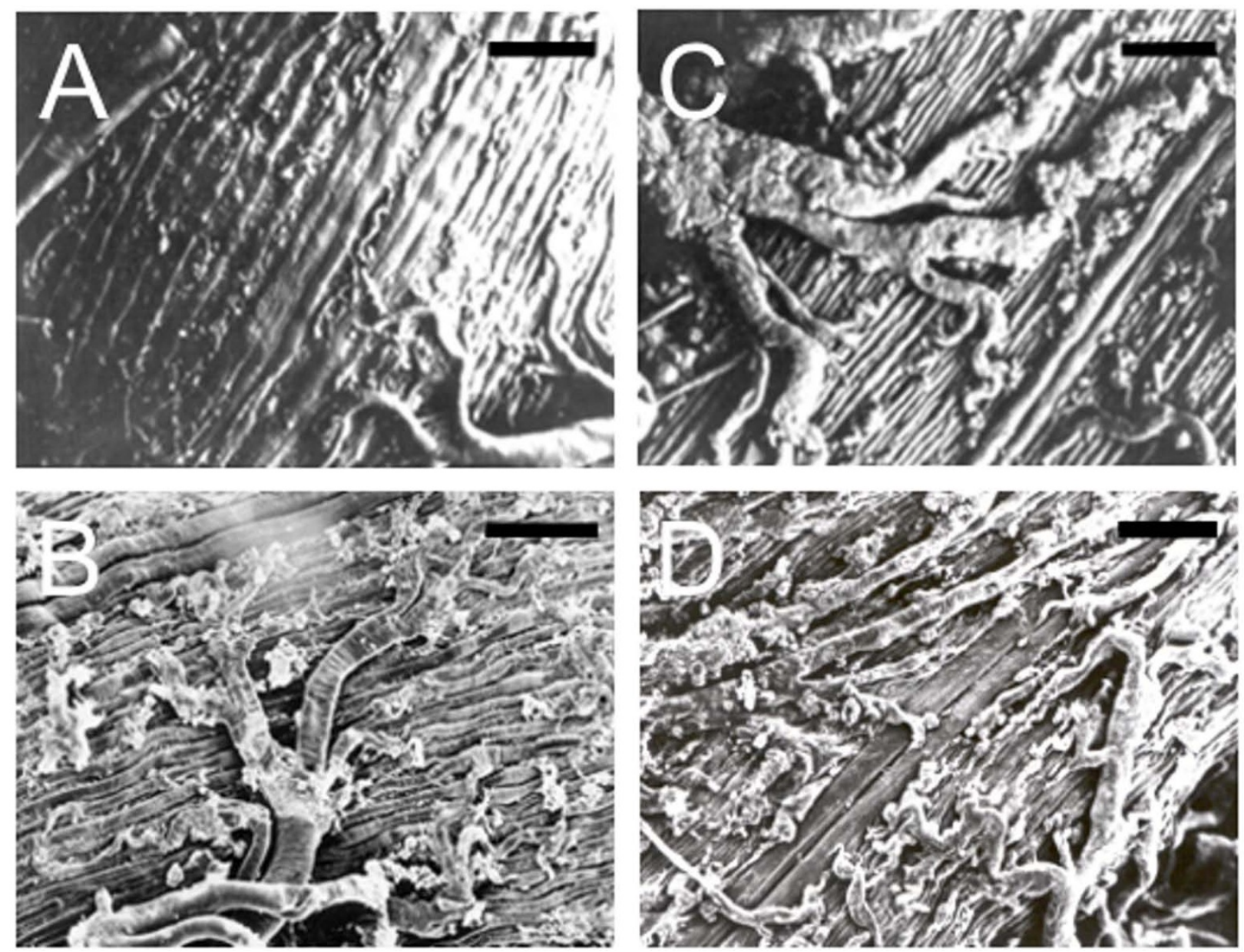

Figure 4 Ultrastructure of S. frugiperda midgut from virus-infected insects at 96. h.p.i. Scanning electron micrographs showing the integrity of the tissue around the gut of the caterpillar uninfected (A), tracheal system tightly attached to the midgut and partial destruction of the connective tissue in larvae infected with virus AcMNPV (B) and loosening of the tracheal system and intense tissue destruction in larvae infected with vSynScathL (C) and vSynKerat (D). Bar $100 \mu \mathrm{M}$.

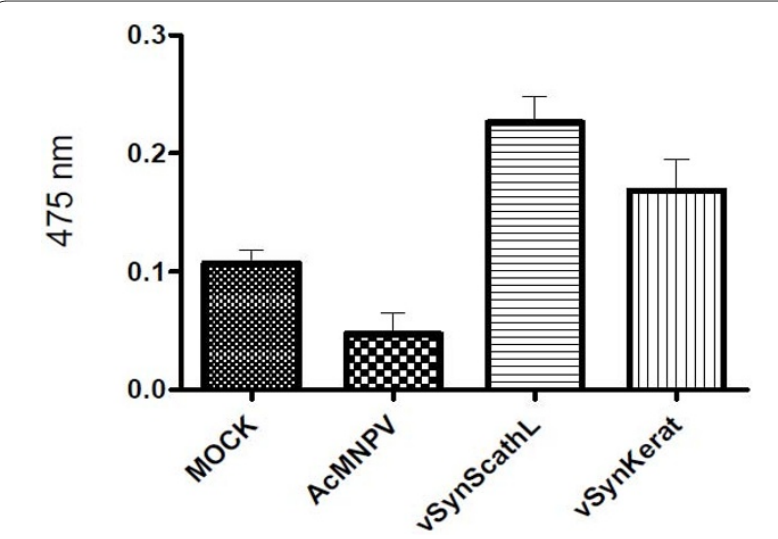

Figure 5 Phenoloxidase activity in haemolymph of infected S. frugiperda larvae. The haemolymph was collected at $72 \mathrm{~h}$ p.i., the cell removed by centrifugation and phenoloxidase activity was determined spectrophotometrically using the cell-free hemolymph $(113 \mu \mathrm{g})$ and $\mathrm{L}-$ 3, 4-dihydroxyphenylalanine (L-DOPA) as a substrate. The experiment was repeated 3 times. Note that haemolymph from insects infected with the recombinant vSynScathL and vSynKerat showed increased activation of the enzyme to increase phenoloxidase activity in the hemolymph of $S$. frugiperda larva. Since the Keratinase is a serine protease this result was not a surprise, since insect serine proteases are known to be involved in melanin production [71]. The increased hemolymph phenoloxidase activity by the vSynScathL could be explained, in part, by the high level of expression of this protein in infected insects. However, further analysis will be necessary to clarify the role of the ScathL in this increase in pheoloxidase activity.

\section{Conclusions}

Although recombinant baculoviruses have not yet been widely used for the control of insect pests, they constitute a viable alternative to chemical insecticides. The recombinant baculoviruses containing protease genes can be added to list of engineered baculoviruses with great potential to be used in integrated pest management programs.

\section{Competing interests}

The authors declare that they have no competing interests. 


\section{Authors' contributions}

AWG carried out the study, performed analysis of data and drafted the manuscript SP helped with the construction of recombinant viruses and with the structural and ultrastructural analysis of virus-infected $S$. frugiperda larvae. RLBS helped with bioassays. EFN and CRF developed the phenoloxidase assay protocol and provided the Keratinase gene. TN participated in the study design and sequencing of DNA constructs. BMR conceived the study, provided research funds, students supervision and revised the manuscript. All authors have read and approved the final manuscript.

\section{Acknowledgements}

We are dearly indebted to Dr. Rose Monnerat from Embrapa Recursos Genéticos e Biotecnologia, Brasília, DF, Brazil, for her kind supply of S. frugiperda larvae, and to Dr. Robert Harrison from lowa State University, USA for DNA from the pKYH5 plasmid. This work was supported by the following Brazilian agencies: CNPq, CAPES, FAPDF.

\section{Author Details}

Cell Biology Department, University of Brasília, Brasília, DF, CEP 70910-970, Brazil

Received: 14 April 2010 Accepted: 29 June 2010

Published: 29 June 2010

\section{References}

1. Gröner A: Specificity and safety of baculoviruses. In The biology of baculoviruses Volume 1. Edited by: Granados RR, Federici BA. Boca Raton: CRC; 1986:177-202.

2. Moscardi F: Utilização de vírus entomopatogênicos em campo. In Controle microbiano de insetos Edited by: Alves SB. Piracicaba: FEALQ 1999:509-539.

3. Castro MEB, Souza ML, Sihler W, Rodrigues JCM, Ribeiro BM: Molecular biology of baculovirus and its use in biological control in Brazil. Pesquisa Agropecuaria Brasileira 1999, 34:1733-1761

4. Lauzon HAM, Garcia-Maruniak A, Zanotto P, Clemente JC, Herniou EA Lucarotti CJ, Arif BM, Maruniak JE: Genomic comparison of Neodiprion sertifer and Neodiprion lecontei nucleopolyhedroviruses and identification of potential hymenopteran baculovirus-specific open reading frames. J Gen Virol 2006, 87:1477-1489.

5. Smith GE, Vlak JM, Summers MD: Physical analysis of Autographa californica nuclear polyhedrosis-virus transcripts for polyhedrin and 10,000-molecular-weight protein. J Gen Virol 1983, 45:215-225.

6. Jehle JA, Blissard GW, Bonning BC, Cory JS, Herniou EA, Rohrmann GF, Theilmann DA, Thiem SM, Vlak JM: On the classification and nomenclature of baculoviruses: A proposal for revision. Arch Virol 2006, 151:1257-1266.

7. Smith CR, Heinz KM, Sansone CG, Flexner JL: Impact of recombinant Baculovirus applications on target heliothines and nontarget predators in cotton. Biol Control 2000, 19:201-214

8. Treacy MF, Rensner PE, All JN: Comparative insecticidal properties of two nucleopolyhedrovirus vectors encoding a similar toxin gene chimer. J Econ Entomol 2000, 93:1096-1104.

9. Van Beek NAM, Hughes PR: The response time of insect larvae infected with recombinant baculoviruses. J Invertebr Patho/ 1998, 72:338-347.

10. Cory JS, Hirst ML, Williams T, Hails RS, Goulson D, Green BM, Carty TM, Possee RD, Cayley PJ, Bishop DHL: Field trial of a genetically improved baculovirus insecticide. Nature 1994, 370:138-140.

11. Mccutchen BF, Choudary PV, Crenshaw R, Maddox D, Kamita SG, Palekar $\mathrm{N}$, Volrath S, Fowler E, Hammock BD, Maeda S: Development of a recombinant baculovirus expressing an insect-selective neurotoxin potential for pest-control. BioTechnology (N Y) 1991, 9:848-852.

12. Stewart LMD, Hirst M, Ferber ML, Merryweather AT, Cayley PJ, Possee RD: Construction of an improved baculovirus insecticide containing an insect-specific toxin gene. Nature 1991, 352:85-88

13. Tomalski MD, Miller LK: Expression of a paralytic neurotoxin gene to improve insect baculoviruses as biopesticides. BioTechnology (NY) 1992, 10:545-549.

14. Treacy MF, All JN: Impact of insect-specific aahit gene insertion on inherent bioactivity of baculovirus against tobacco budworm, Heliothis virescens, and cabbage looper Trichoplusia ni. Proceedings of the Beltwide Cotton Conference: 911-917, Nashville 1996.
15. Maeda S: Increased insecticidal effect by a recombinant baculovirus carrying a synthetic diuretic hormone gene. Biochem Biophys Res Commun 1989, 165:1177-1183.

16. Hammock BD, Bonning BC, Possee RD, Hanzlik TN, Maeda S: Expression and effects of the juvenile-hormone esterase in a baculovirus vector. Nature 1990, 344:458-461.

17. Booth TF, Bonning BC, Hammock BD: Localization of juvenile-hormone esterase during development in normal and in recombinant baculovírus infected larvae of the moth Trichoplusia-ni. Tissue Cell 1992, 24:267-282

18. Roelvink PW, Vanmeer MMM, Dekort CAD, Possee RD, Hammock BD, Vlak JM: Dissimilar expression of Autographa californica multiple nucleocapsid nuclear polyhedrosis-virus polyhedron and p10 genes. $J$ Gen Virol 1992, 73:1481-1489.

19. Eldrigde R, O'Reilly DR, Hammock BD, Miller LK: Insecticidal properties of genetically engineered baculovirus expressing an insect juvenile hormone esterase gene. Appl Environ Microbiol 1992, 58:1583-1591

20. Bonning BC, Possee RD, Hammock BD: Insecticidal efficacy of a recombinant baculovirus expressing JHE-KK, a modified juvenile hormone esterase. J Invertebr Pathol 1999, 73:234-236.

21. O'Reilly DR, Miller LK: A baculovirus blocks insect molting by producing ecdysteroid udp-glucosyl transferase. Science 1989, 245:1110-1112.

22. Rodrigues JCM, De Souza ML, O'Reilly D, Velloso LM, Pinedo FJR, Razuck FB, Ribeiro B, Ribeiro BM: Characterization of the ecdysteroid UDPGlucosyltransferase (egt) gene of Anticarsia gemmatalis nucleopolyhedrovirus. Virus Genes 2001, 22:103-112.

23. Pinedo FJR, Moscardi F, Luque T, Olszewski JA, Ribeiro BM: Inactivation of the ecdysteroid UDP-glucosyltransferase (egt) gene of Anticarsia gemmatalis nucleopolyhedrovirus (AgMNPV) improves its virulence towards its insect host. Biol Control 2003, 27:336-344.

24. Popham HJR, Bischoff DS, Slavicek JM: Both Lymantria dispar nucleopolyhedrovirus Enhancin genes contribute to viral potency. J Virol 2001, 75:8639-8648

25. Li Q, Li L, Moore K, Donly C, Theilmann DA, Erlandson M: Characterization of Mamestra configurata nucleopolyhedrovirus enhancing and its functional analysis via expression in an Autographa californica M nucleopolyhedrovirus recombinant. J Gen Virol 2003, 84:123-132.

26. Hayakawa T, Shimojo E, Mori M, Kaido M, Furusawa I, Miyata S, Sano Y, Matsumoto T, Hashimoto Y, Granados RR: Enhancement of baculovirus infection in Spodoptera exigua (Lepidoptera: Noctuidae) larvae with Autographa californica nucleopolyhedrovirus or Nicotiana tabacum engineered with a granulovirus enhancin gene. Appl Entomol Zool 2000, 35:163-170

27. Kramer KJ, Muthukrishnan S: Insect chitinases: Molecular biology and potential use as biopesticides. Insect Biochem Mol Biol 1997, 27:887-900.

28. Merzendorfer $\mathrm{H}$, Zimoch L: Chitin metabolism in insects: structure, function and regulation of chitin synthases and chitinases. J Exp Biol 2003, 206:4393-4412.

29. Gooday GW: Agressive and defensive roles for chitinases. In Chitin and Chitinases Edited by: Muzzarelli RAA, Jolles P. Birkhäuserverlag; 1999:157-169.

30. Hawtin RE, Arnold K, Ayres MD, Zanotto PMD, Howard SC, Gooday GW Chappell LH, Kitts PA, King LA, Possee RD: Identification and preliminary characterization of a chitinase gene in the Autographa californica nuclear polyhedrosis-virus genome. Virology 1995, 212:673-685.

31. Hawtin RE, Zarkowska T, Arnold K, Thomas CJ, Gooday GW, King LA, Kuzio JA, Possee RD: Liquefaction of Autographa californica nucleopolyhedrovirus-infected insects is dependent on the integrity of virus-encoded chitinase and cathepsin genes. Virology 1997 , 238:243-253.

32. Merryweather AT, Weyer U, Harris MPG, Hirst M, Booth T, Possee RD: Construction of genetically engineered baculovirus insecticides containing the Bacillus thuringiensis subsp kurstaki HD-73 deltaendotoxin. J Gen Virol 1990, 71:1535-1544.

33. Pang Y, Frutos R, Federici BA: Synthesis and toxicity of full-length and truncated bacterial cryivd mosquitocidal proteins expressed in lepidopteran cells using a baculovirus vector. J Gen Virol 1992, 73:89-101.

34. Ribeiro BM, Crook NE: Expression of full-length and truncated forms of crystal protein genes from Bacillus thuringiensis subsp kurstaki in a baculovirus and pathogenicity of the recombinant viruses. J Invertebr Pathol 1993, 62:121-130. 
35. Ribeiro BM, Souza ML, Kitajima EW: Taxonomia, Caracterização e bioquímica de vírus de insetos. In Alves, BS Controle Microbiano de Insetos Edited by: UNESP. São Paulo; 1998:481-503.

36. Martens JWM, Knoester M, Weijts F, Groffen SJA, Hu ZH, Bosch D, Vlak JM: Characterization of baculovirus insecticides expressing tailored Bacillus thuringiensis CrylA(b) crystal proteins. J Invertebr Pathol 1995, 66:249-257.

37. Chang JH, Choi JY, Jin BR, Roh JY, Olszewski JA, Seo SJ, O'Reilly DR, Je YH: An improved baculovirus insecticide producing occlusion bodies that contain Bacillus thuringiensis insect toxin. I Invertebr Pathol 2003, 84:30-37.

38. Harrison RL, Bonning BC: Use of proteases to improve the insecticidal activity of baculoviruses. Biol Control 2001, 20:199-209.

39. Cruz I, Figueiredo M, De LC, Matoso MJ: Controle Biológico de Spodoptera frugiperda utilizando o parasitóide de ovos Trichogramma. Sete Lagoas. In Circular Técnica 30 Empresa Brasileira de Pesquisa Agropecuária (Embrapa), Embrapa Milho e Sorgo; 1999.

40. Praça LB, Silva Neto SB, Monnerat RG: Spodoptera frugiperda J. Smith 1797 (Lepidoptera: Noctuidae) Biologia, amostragem e métodos de controle. In Documentos 199 Empresa Brasileira de Pesquisa Agropecuária (Embrapa), Embrapa Recursos Genéticos e Biotecnologia; 2006

41. Frosco M, Chase T, Macmillan JD: Purification and properties of the elastase from Aspergillus-fumigatus. Infect Immun 1992, 60:728-734.

42. Markaryan A, Morozova I, Yu HS, Kolattukudy PE: Purification and characterization of an elastinolytic metalloprotease from Aspergillus fumigatus and immunoelectron microscopic evidence of secretion of this enzyme by the fungus invading the murine lung. Infect Immun 1994, 62:2149-2157.

43. Moser M, Menz G, Blaser K, Crameri R: Recombinant expression and antigenic properties of a 32-kilodalton extracellular alkaline protease, representing a possible virulence factor from Aspergillus fumigatus. Infect Immun 1994, 62:936-942

44. Larcher G, Bouchara JP, Annaix V, Symoens F, Chabasse D, Tronchin G: Purification and characterization of a fibrinogenolytic serine proteinase from Aspergillus fumigatus culture filtrate. FEBS Lett 1992 308:65-69.

45. Monod M, Paris S, Sanglard D, Jatonogay K, Bille J, Latge JP: Isolation and characterization of a secreted metalloprotease of Aspergillus fumigatus. Infect Immun 1993, 61:4099-4104.

46. Noronha EF, de Lima BD, De Sa CM, Felix CR: Heterologous production of Aspergillus fumigatus keratinase in Pichia pastoris. World J Microb Biot 2002, 18:563-568.

47. Granados RR, Li GX, Derksen ACG, mckenna KA: A new insect-cell line from Trichoplusia ni (bti-tn-5b1-4) susceptible to Trichoplusia ni single enveloped nuclear polyhedrosis-virus. J Invertebr Pathol 1994 64:260-266

48. Vaughn JL, Goodwin RH, Tompkins GJ, Mccawley P: Establishment of 2 cell lines from insect Spodoptera frugiperda (Lepidoptera-Noctuidae). In Vitro 1977, 13:213-217.

49. Wang XZ, Ooi BG, Miller LK: Baculovirus vectors for multiple geneexpression and for occluded virus production. Gene 1991, 100:131-137.

50. Sambrook J, Roussell DW: Molecular Cloning A Laboratory Manual New York: Cold Spring Harbor Laboratory Press; 2001.

51. O'Reilly DR, Miller LK, Luckow VA: Baculovirus Expression Vectors: A Laboratory Manual New York: W.H. Freeman and Company; 1992.

52. Hughes PR, Wood HA: A synchronous peroral technique for the bioassay of insect viruses. J Invertebr Pathol 1981, 37:154-159.

53. Morales L, Moscardi F, Sosa-Gomez DR, Paro FE, Soldorio IL: Fluorescent brighteners improve Anticarsia gemmatalis (Lepidoptera: Noctuidae) nucleopolyhedrovirus (AgMNPV) activity on AgMNPV susceptible and resistant strains of the insect. Biol Control 2001, 20:247-253.

54. Matos TGT, Giugliano LG, Ribeiro BM, Bao SN: Structural and ultrastructural studies of Anticarsia gemmatalis midgut cells infected with the baculovirus A. gemmatalis nucleopolyhedrovirus. Int I Insect Morphol Embryol 1999, 28:195-201.

55. Ghosh S, Parvez MK, Banerjee K, Sarin SK, Hasnain SE: Baculovirus as mammalian cell expression vector for gene therapy: An emerging strategy. Mol Ther 2002, 6:5-11.

56. Luckow VA, Summers MD: Trends in the development of baculovirus expression vectors. BioTechnology (N Y) 1988, 6:47-55.
57. Richardson CD: Baculovirus expression protocols. Methods Mol Biol 1995, 39:418.

58. Jarvis DL: Baculovirus expression vectors. In The Baculoviruses Edited by: Miller LK. New York: Plenum Press; 1997:389-431.

59. Bonning BC, Ward VK, Vanmeer MMM, Booth TF, Hammock BD: Disruption of lysosomal targeting is associated with insecticidal potency of juvenile hormone esterase. Proc Natl Acad Sci USA 1997, 94:6007-6012

60. Tomalski MD, Miller LK: Insect paralysis by baculovirus-mediated expression of a mite neurotoxin gene. Nature 1991, 352:82-85

61. Lu A, Seshagiri S, Miller LK: Signal sequence and promoter effects on the efficacy of toxin-expressing baculoviruses as biopesticides. Bio/ Control 1996, 7:320-332.

62. Zlotkin E, Fishman Y, Elazar AAIT: From neurotoxin to insecticide. Biochimie 2000, 82:869-881.

63. Froy O, Zilberberg N, Chejanovsky N, Anglister J, Loret E, Shaanan B, Gordon D, Gurevitz M: Scorpion neurotoxins: structure/function relationships and application in agriculture. Pest Manag Sci 2000, 56:472-474

64. Imai N, Ali SES, El-Singabi NR, Iwanaga M, Matsumoto S, Iwabuchi K Maeda S: Insecticidal effects of a recombinant baculovirus expressing a scorpion toxin LqhiT2. J Seric Sci Jpn 2000, 69:197-205.

65. Prikhod'ko Prikhod'ko GG, Popham HJR, Felcetto TJ, Ostlind DA, Warren VA, Smith MM, Garsky VM, Warmke JW, Cohen CJ, Miller LK: Effects of simultaneous expression of two sodium channel toxin genes on the properties of baculoviruses as biopesticides. Biol Control 1998, 12:66-78.

66. Li HR, Tang HL, Sivakumar S, Philip J, Harrison RL, Gatehouse JA, Bonning $\mathrm{BC}$ : Insecticidal activity of a basement membrane-degrading protease against Heliothis virescens (Fabricius) and Acyrthosiphon pisum (Harris). $J$ Insect Physiol 2008, 54:777-789.

67. Clarke T, Clem RJ: Lack of involvement of haemocytes in establishment and spread of infection in Spodoptera frugiperda larvae infected with the baculovirus Autographa californica M nucleopolyhedrovirus by intrahaemocoelic injection. J Gen Virol 2002, 83:1565-1572.

68. Blanco JL, Hontecillas R, Bouza E, Blanco I, Pelaez T, Munoz P, Molina JP, Garcia ME: Correlation between the elastase activity index and invasiveness of clinical isolates of Aspergillus fumigatus. J Clin Microbiol 2002, 40:1811-1813.

69. Kolattukudy PE, Lee LD, Rogers LM, Zimmerman P, Ceselski S, Fox B, Stein B, Copelan EA: Evidence for a possible involvement of an elastolytic serine protease in Aspergillosis. Infect Immun 1993, 61:2357-2368.

70. Stleger RJ, Joshi L, Bidochka MJ, Roberts DW: Construction of an improved mycoinsecticide overexpressing a toxic protease. Proc Nat Acad Sci USA 1996, 93:6349-6354.

71. Cerenius L, Soderhall K: The prophenoloxidase-activating system in invertebrates. Immunol Rev 2004, 198:116-126.

72. Tang H, Li H, Lei SM, Harrison RL, Bonning BC: Tissue specificity of a baculovirus-expressed, basement membrane-degrading protease in larvae of Heliothis virescens. Tissue Cell 2007, 39:431-443.

73. Li HR, Tang HL, Harrison RL, Bonning BC: Impact of a basement membrane-degrading protease on dissemination and secondary infection of Autographa californica multiple nucleopolyhedrovirus in Heliothis virescens (Fabricus). J Gen Virol 2007, 88:1109-1119.

doi: $10.1186 / 1743-422 X-7-143$

Cite this article as: Gramkow et al., Insecticidal activity of two proteases against Spodoptera frugiperda larvae infected with recombinant baculoviruses Virology Journal 2010, 7:143 